\title{
Atopic dermatitis-like disease in a rat model
}

\author{
Modelo tipo de dermatite atópica em rato
}

\section{Raquel CS Barcelos ${ }^{1,2,3,4}$, Cristina de Mello-Sampayo ${ }^{2,3}$, CTD Antoniazzi ${ }^{1}$, HJ Segat ${ }^{1}$, H Silva ${ }^{3,4}$,}

ME Bürger ${ }^{1}$, Beatriz Silva-Lima ${ }^{2,3}$, LM Rodrigues ${ }^{2,3,4}$

${ }^{1}$ Programa de Pós-Graduação em Farmacologia, Universidade Federal de Santa Maria (UFSM), RS, Brazil

${ }^{2}$ iMed Research Institute for Medicines and Pharmaceutical Sciences, Faculty of Pharmacy, University of Lisbon, Lisbon, Portugal.

${ }^{3}$ Pharmacological Sc Department, Faculty of Pharmacy, University of Lisbon, Lisbon, Portugal. ${ }^{4}$ CBIOS, University Lusófona's Research Center for Bioscience and Health Technologies, Lisboa, Portugal Email: raquel.barcelos@hotmail.com

\begin{abstract}
The Atopic dermatitis (AD) is a most important topic in clinical dermatology. In fact, the pathogenesis of this chronic inflammatory skin disease, primarily characterized by pruritus and dry skin, is still far from being fully understood. To look further into this complex disease, male adult Wistar rats $(n=10)$ were used as a model where acetone (AA) acted as the active challenger in a 3-day treatment setting, and compared with water (AW). On day 3 , one hour after the last treatment, the AA area exhibited higher transepidermal water loss (TEWL), capillary blood flow, and reduced hydration when compared to AW. The scratching behavior was markedly higher in the AA treated group $(n=5)$ than in the AW group $(n=5)$. These interesting results justify the application of this model as a clinical experimental tool for AD research.
\end{abstract}

Keywords: atopic dermatitis; pathophysiology; animal model; inflammation, pruritus

\section{Resumo}

A dermatite atópica (DA) é um tema importante na dermatologia clínica. Na verdade, a patogénese dessa doença inflamatória crónica da pele, caracterizada principalmente por pele seca e prurido, ainda está longe de ser totalmente compreendida. A fim de saber mais acerca desta complexa doença, ratos Wistar machos e adultos $(n=10)$ foram utilizados como modelo animal, nos quais o tratamento com acetona (AA) foi comparado com o tratamento com água por 3 dias (AW). No dia 3, uma hora após o último tratamento, a AA mostrou maior perda transepidérmica de água (TEWL), fluxo sanguíneo capilar e reduzida hidratação quando comparada com AW. A análise comportamental mostrou que a acção de coçar foi marcadamente mais frequente no grupo AA $(n=5)$ quando comparado ao grupo AW $(n=5)$. Estes resultados justificam a implementação deste modelo animal como uma ferramenta experimental para investigação da $\mathrm{AD}$.

Palavras-chave: dermatite atópica, fisiopatologia, modelo animal, inflamação, prurido 


\section{Introduction}

Dry skin is a common global problem [1]. Recent studies from the USA, France and Japan report that $40 \%$ of the population apparently suffers from a dry skin related problem [2]. Dry skin, or xerotic eczema, can be diagnosed as xerosis, asteatotic eczema, deshydrotic eczema or eczema craquelé [3]. Scaly, rough, fissured / cracked surface are typical in dry skin and such dermatological conditions are closely related to the unpleasant somatosensory sensation of itching or pruritus [3-5]. Skin dryness is present in many pruritic cutaneous diseases, such as xerosis and atopic dermatitis (AD), which is actually the most prevalent hallmark of these conditions involving dry skin and pruritus [6]. AD is the most common higher occurrence inflammatory skin condition during infancy and childhood [7] so that in the last two decades, its prevalence has increased between $18 \%$ and $25 \%$ in some developed countries [8]. AD is noncontagious and characterized in acute phases by intense itching, erythematous rash, vesicles and oedema, and lichenification in chronic stages $[7,9,10]$. Patients with $\mathrm{AD}$-induced visible dermatologic signs and disruptive symptoms have their lives and social relationships negatively affected, with reduced sense of well-being and self-esteem, anxiety, psychosocial stress, sleep deprivation, and poor professional performance [11]. AD complex pathogenesis still remains unclear and only partially understood [7] despite improved knowledge of the topic due to growing research, especially in recent years. It is thought to result from a complex interaction between the skin barrier disruption, immune abnormalities, and environmental and infectious agents [12].

The present study aims to develop an animal model, where a controlled AD-like condition is evoked, in order to look deeper into the pathophysiological processes involved in this skin disease.

\section{Materials and methods}

\section{Animals}

Male Wistar rats weighing $(447 \pm 14) \mathrm{g}(n=10)$ were obtained from Harlan Laboratories Inc. (Barcelona, Spain). The animals were housed under controlled temperature (between $20^{\circ} \mathrm{C}$ and $24^{\circ} \mathrm{C}$ ) and $12 \mathrm{~h} \mathrm{light/dark}$ cycle (light between 07:00 and 19:00). Food and water were freely available. Animals were fed with standard laboratory chow (4RF21 GLP; Mucedolasrl, Milan, Italy). Procedures for animal experiments were conducted in accordance with the relevant European Community

\section{Introdução}

A pele seca é um problema global comum [1]. Estudos recentes dos EUA, França e Japão relataram que 40 $\%$ da população sofre aparentemente de um problema relacionado com a pele seca [2]. A pele seca ou eczema xerótico pode ser diagnosticado como xerose, eczema asteatótico, eczema desidrótico ou eczema craquelé [3]. A superfície seca, escamosa e fissurada/rachada são típicas na pele seca e tais condições dermatológicas estão intimamente relacionadas com a desagradável sensação somatossensorial de coceira ou prurido [3-5]. O ressecamento da pele está presente em muitas doenças cutâneas pruriginosas, como a xerose e a dermatite atópica (DA), a qual é, atualmente, a característica mais prevalente das condições que envolvem a pele seca e o prurido [6]. A DA é a condição inflamatória da pele de maior ocorrência durante a infância [7], e nas duas últimas décadas, a sua prevalência aumentou entre $18 \% \mathrm{e}$ $25 \%$ em alguns países desenvolvidos [8]. A DA não é contagiosa e caracteriza-se, na sua fase aguda, por prurido intenso, exantema eritematoso, vesículas e edema, e liquenificação na fase crônica $[7,9,10]$. Pacientes com sinais dermatológicos visíveis induzidos pela DA têm suas vidas e relações sociais negativamente afetadas, com redução da sensação de bem-estar e auto-estima, ansiedade, estresse psicossocial, privação de sono e baixo desempenho profissional [11]. Apesar do conhecimento aprimorado proporcionado pela investigação crescente, especialmente nos últimos anos, a complexa patogênese da DA permanece obscura e ainda parcialmente compreendida [7], e pode ser resultado de uma complexa interação entre o comprometimento da barreira da pele, anormalias imunológicas e a acção de agentes ambientais e infecciosos [12].

O presente estudo teve como objetivo desenvolver um modelo animal de DA sob condições controladas, a fim de saber mais acerca dos processos fisiopatológicos envolvidos nessa doença de pele.

\section{Materiais e métodos}

Animais

Ratos Wistar machos pesando $(447 \pm 14)$ g $(n=10)$ foram obtidos ao Laboratório Harlan Inc. (Barcelona, Espanha). Os animais foram mantidos sob temperatura controlada (entre $20{ }^{\circ} \mathrm{C}$ e $24{ }^{\circ} \mathrm{C}$ ), ciclo claro/escuro de 12h (luz acesas entre 7:00 e 19:00) e comida e água $a d$ libitum e alimentados com ração padrão (BPL 4RF21; Mucedolasrl, Milão, Itália). Os procedimentos de experimentação animal foram conduzidos em harmonia com as regras aplicadas na União Europeia, consideran- 
and National rules on animals $\square$ protection for experimental and other scientific purposes [13-15].

\section{Chemicals}

Acetone and ether were acquired from Sigma Chemicals Co. (St. Louis, MO, USA).

\section{Cutaneous barrier alteration}

The rats' dorsal body hair $(6 \mathrm{~cm}$ x $6 \mathrm{~cm})$ was removed $24 \mathrm{~h}$ before the experiment by an electric razor followed by a soft hair-removing cream. The animal dorsum was divided by the median line into two areas. To modify the animal's epidermal barrier, the left side of the area was exposed to acetone, applied with soaked cotton wool $(3 \mathrm{~cm} \mathrm{x} 3 \mathrm{~cm})$ for 5 min (acetone area; $A A)$, while the right side was exposed to sterile water (water area; $W A$ ) and served as the control (Figure 1). This procedure took place for 3 consecutive days (at 9:00AM) under deep sedation induced by inhalation of ether to prevent additional stress stimulus. On day 3 , approximately $1 \mathrm{~h}$ after the last application, the skin physiology and the scratching behavior were assessed.

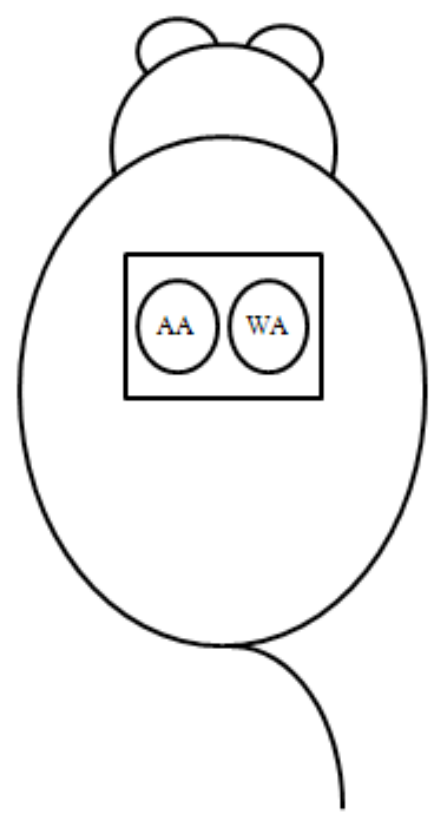

Figure 1

Graphic scheme illustrating the preparation of the model for the experimental procedure. The marked dorsal area on the left was exposed to acetone (AA) and the right area exposed to sterile water (WA) served as the control (see text).

\section{Figura 1}

Esquema gráfico ilustrando o modelo para o procedimento experimental. A região dorsal da esquerda foi exposta à acetona (AA), a área dorsal à direita foi exposta à água estéril (WA) e serviu como controlo (ver texto). do ainda as regras nacionais aplicáveis à proteção para experimentação animal e outros fins científicos [13-15].

\section{Químicos}

A acetona e o éter foram adquiridos da Sigma Chemical Co. (St. Louis, MO, EUA).

\section{Alteração da barreira cutânea}

O pêlo dorsal dos ratos foi removida $(6 \mathrm{~cm} \times 6 \mathrm{~cm}) 24 \mathrm{~h}$ antes das experiências com auxílio de um barbeador elétrico, seguido da aplicação tópica de um creme depilatório. $\mathrm{O}$ dorso dos animais foi divididos pela linha mediana em duas áreas. Para modificar barreira epidérmica do animal, a área do lado esquerdo foi exposta à acetona, aplicada com um algodão embebido $(3 \mathrm{~cm} \mathrm{x}$ $3 \mathrm{~cm}$ ) durante $5 \mathrm{~min}$ (área da acetona, AA), enquanto a área do lado direito foi exposta à água esterilizada (área da água, WA) e serviu como controlo (Figura 1). Este procedimento foi realizado durante três dias consecutivos (9:00AM), sob sedação profunda induzida por inalação de éter para prevenir qualquer estímulo estressante ao animal. No dia 3, cerca de $1 \mathrm{~h}$ após a última aplicação, a fisiologia da pele e a acção de coçar foram avaliados.

\section{Skin physiology}

The rats $\square$ skin physiology was assessed by non-invasive techniques providing the quantitative measurement of the epidermal barrier, the epidermal water content, and local microcirculation, all obtained in both dorsum (WA and AA )treated areas during sedation. The epidermal barrier, expressed by the Transepidermal Water Loss (TEWL) was measured by evaporimetry using the Tewameter TM300 (Courage+Khazaka GmbH, Cologne, RFA) system and its unit has the symbol $\left(\mathrm{g} \mathrm{h}^{-1}\right.$

\section{Fisiologia da pele}

A fisiologia da pele dos ratos foram avaliadas através de métodos não-invasivos, proporcionando a medição quantitativa da barreira epidérmica, do teor de água da epiderme, e da microcirculação local, todos obtidos em ambas as áreas dorsais (WA e AA) tratadas sob sedação. A barreira epidérmica, medida pela perda de água transepidérmica $(T E W L)$ foi obtida através de evaporimetria usando o sistema Tewameter TM300 (Courage + Khazaka GmbH, Colônia, Alemanha), tendo como símbolo de 
$\mathrm{m}^{-2}$ ). Epidermal water was obtained by an electrometric system, a Corneometer CM825 (Courage+Khazaka Electronic GmbH, Cologne, Germany) expressed in arbitrary units (UA $\square$ s). Local capillary blood flow was determined by laser Doppler flowmetry (LDF) (PeriFlux PF5000, PF5010 System, Perimed, Sweden) expressed in arbitrary units (BPU $\square$ s). Measurements took place $1 \mathrm{~h}$ after the last exposure (day 3 ) under controlled temperature and humidity conditions ( $(22 \pm 4)$ $\left.{ }^{\circ} \mathrm{C},(45 \pm 5) \% r h\right)$, and were expressed as mean values (obtained from 3 sequential assessments).

\section{Scratching behavior}

Evaluation of the scratching behavior was performed according to the protocol described by Okawa et al. [16]. Male Wistar rats (10-week-old), randomly assigned to 2 experimental groups $(n=5)$ according to the previously described procedure were exposed to the acetone challenge test. For the control group, sterile water was used instead of acetone. After $1 \mathrm{~h}$ of the last cutaneous exposure to acetone or sterile water, each rat was individually placed into an acrylic box $(60 \mathrm{~cm} \times 34 \mathrm{~cm}$ $\mathrm{x} 18 \mathrm{~cm}$ ) and acclimatised to the experimental environment for $5 \mathrm{~min}$. The number of scratching actions was counted for 30 minutes by trained observers unaware of the treatments. One scratching action corresponds to a series of scratch movements on the dorsal skin using the hind paws, as previously reported $[16,17]$ and is expressed as a scratching behavior number for each animal for a $30 \mathrm{~min}$ period.

\section{Statistical analysis}

All data are presented as mean \pm SEM. The skin TEWL, hydration, capillary blood flow and scratching behavior data were analyzed using the Wilcoxon test. Differences were considered statistically significant when $p \leq 0,05$. All statistical analyses were carried out using Prisma software.

\section{Results}

Transepidermal Water Loss (TEWL), skin hydration and capillary blood flow of the skin

Following the acetone exposure the TEWL markedly increased, by nearly 4 times $(\mathrm{p}=0,0059)$, when compared with the control (Table 1 and Figure 2A). On the contrary, the skin hydration decreased in the area $(p=0,0020)$ to half of the control value (Table 1 and Figure 2B). The acetone exposure also significantly increased $(p=0,0020)$ the capillary blood flow when compared to the control (Table 1 and Figure 2C). unidade $\mathrm{g} \mathrm{h}^{-1} \mathrm{~m}^{-2}$ ). Aágua da epiderme foi medida por um sistema eletrométrico, o Corneometer CM825 (Courage + Khazaka Electronic GmbH, Colônia, Alemanha), e expressa em unidades arbitrárias (UA'S). O fluxo sanguíneo capilar local foi determinado por Laser Doppler (LDF) (PeriFlux PF5000, PF5010 System, Perimed, Suécia) expresso em unidades arbitrárias (BPU's). As medições foram realizadas $1 \mathrm{~h}$ após a última exposição (dia 3) sob condições de temperatura e umidade controladas ( $(22 \pm 4)$ $\left.{ }^{\circ} \mathrm{C}, 45 \pm 5\right) \% h r$ ), e foram expressas como valores médios (obtidos a partir de três avaliações sequenciais).

\section{Análise comportamental}

A avaliação da acção de coçar foi realizada de acordo com o protocolo descrito por Okawa et al. [16]. Ratos machos Wistar (10 semanas de idade), divididos aleatoriamente em dois grupos experimentais $(n=5)$ foram expostos à acetona de acordo com o procedimento descrito anteriormente. Para o grupo controlo, a água estéril foi usada em vez de acetona. Uma hora após a última exposição cutânea à acetona ou à água estéril, cada rato foi colocado individualmente em uma caixa de acrílico (60 cm x $34 \mathrm{~cm} \times 18 \mathrm{~cm})$ e aclimatados ao ambiente experimental durante $5 \mathrm{~min}$. O número de ações de coçar foi mensurado durante $30 \mathrm{~min}$ por observadores treinados desconhecendo os tratamentos. Uma ação de coçar corresponde a uma série de movimentos em direção a pele dorsal usando as patas traseiras, como relatado anteriormente $[16,17]$ e expresso como o número de atos para cada animal durante $30 \mathrm{~min}$.

\section{Análise estatística}

Todos os dados são apresentados como média \pm EPM. A TEWL, a hidratação, o fluxo sanguíneo capilar e os dados da análise comportamental foram analisados utilizando o teste de Wilcoxon. Diferenças estatisticamente significativas foram consideradas quando $p \leq 0,05$. Todas as análises estatísticas foram realizadas utilizando o software Prisma $\square$.

\section{Resultados}

Perda de água transepidérmica (TEWL), hidratação e fluxo sanguíneo capilar da pele

Após a exposição à acetona, a TWEL aumentou acentuadamente, aproximadamente 4 vezes $(p=0,0059)$, quando comparados com o grupo controlo (Tabela 1 e Figura 2A). Contrariamente, a hidratação da pele diminuiu na AA $(p=0,0020)$ para metade do valor do grupo controlo (WA) (Tabela 1 e Figura 2B). A exposição à acetona aumentou significativamente ( $p=$ 0,0020 ) o fluxo sanguíneo capilar quando comparado ao grupo controlo (Tabela 1 e Figura 2C). 
Table 1 - Biometric and behavioral results of the acetone (AA) and water (WA) exposed areas of rats' pre-shaved dorsum skin. For Transepidermal Water Loss (TEWL), hydration and capillary blood flow $n=10$ and $n=5$ for scratching behavioral.

Data expressed as means \pm S.E.M.

Tabela 1 - Resultados biométricos e comportamentais das áreas expostas à acetona (AA) e à água (WA) na pele dorsal pré-depilada de ratos da perda de água transepidérmica $(T E W L)$, hidratação e fluxo sanguíneo capilar $n=10$ e $n=5$ para a análise comportamental. Dados expressos como média \pm E.P.M.

\begin{tabular}{|c|c|c|c|}
\hline & WA & $\mathbf{A A}$ & $p$ \\
\hline$T E W L /\left(\mathrm{g} \mathrm{h}^{-1} \mathrm{~m}^{-2}\right)$ & $7.68 \pm 0.47$ & $28.39 \pm 1.28$ & 0.0059 \\
\hline $\begin{array}{l}\text { Hydration / AU } \\
\text { Hidratação / UA }\end{array}$ & $23.70 \pm 1.98$ & $12.53 \pm 0.71$ & 0.0020 \\
\hline $\begin{array}{l}\text { Capillary blood flow / BPU } \\
\text { Fluxo sanguíneo capilar / BPU }\end{array}$ & $16.56 \pm 0.74$ & $29.09 \pm 1.87$ & 0.0020 \\
\hline $\begin{array}{l}\text { Scratching behavior / (number } / 30 \text { min) / } \\
\text { Ação de coçar / (número / } 30 \text { min) }\end{array}$ & $0.66 \pm 0.50$ & $6.44 \pm 0.16$ & 0.0090 \\
\hline
\end{tabular}
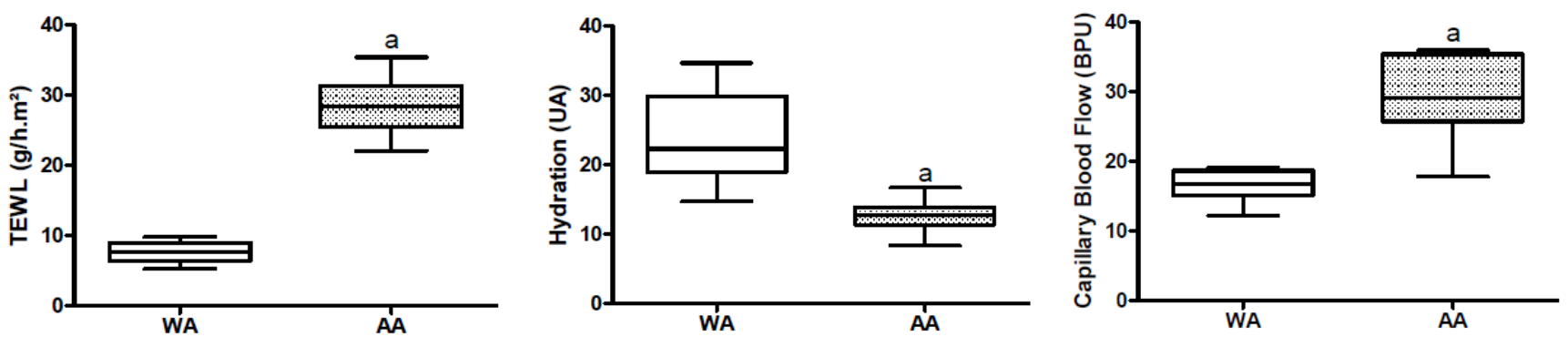

Figure 2 - Effect of acetone exposure of rats' pre-shaved dorsum skin on Transepidermal Water Loss (TEWL) (A), hydration (B) and capillary blood flow (C). Data expressed as means \pm S.E.M $(n=10)$. ${ }^{\text {a }}$ Indicates significant difference between acetone exposed area (AA) and water exposed area (WA) $(p<0,01)$.

Figura 2 - Efeitos da exposição à acetona da pele dorsal pré-depilada de ratos sobre a perda transepidérmica de água $(T E W L)(\mathrm{A})$, hidratação (B) e fluxo sanguíneo capilar (C). Dados expressos como média \pm E.P.M. $(n=10)$. ${ }^{\mathrm{a}}$ Indica a existência de diferença significativa entre a área exposta à acetona (AA) e a exposta à água (WA) $(p<0,01)$.

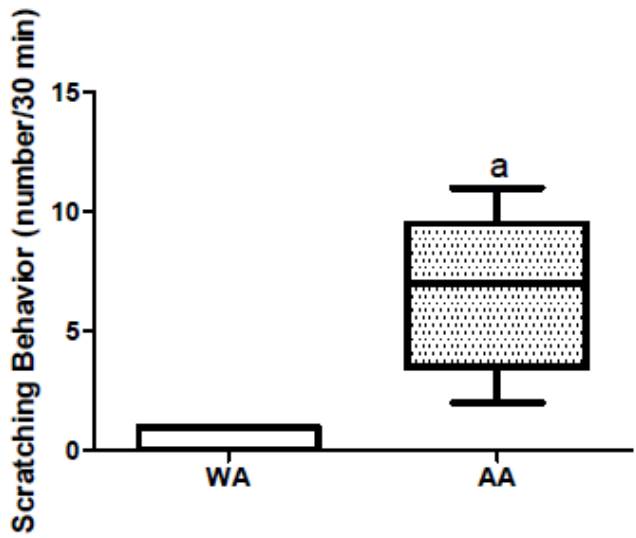

Figure 3 - Rats' scratching behavior (number of scratchings/30 min) $1 \mathrm{~h}$ after the last cutaneous acetone $(n=5)$ or water

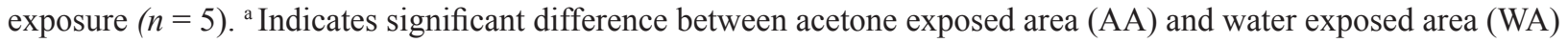
$(p<0,01)$. Data are expressed as mean \pm S.E.M.

Figura 3 - Análise do comportamento dos ratos (número de atos de coçar/30 min) 1 h após a última exposição cutânea à acetona $(n=5)$ ou à água estéril $(n=5)$. ${ }^{\mathrm{a}}$ Indica a existência de diferença significativa entre a área exposta à acetona $(\mathrm{AA}) \mathrm{e}$ a área exposta à água (WA) $(p<0,01)$. Os dados são expressos como média \pm E.P.M. 
The scratching behavior measured by the number of scratching actions registered for $30 \mathrm{~min}$, also changed after the 3 days acetone exposure treatment, significantly increasing $(p=0,0090)$ when compared to the control (Table 1 and Figure 3).

\section{Discussion}

The cellular and molecular mechanisms causing atopic dermatitis (AD) are still unclear, partly due to the limitations of current in vitro research methodologies and the paucity of suitable models.

The main goal for this animal model is to replicate the most relevant features identified in the human AD pathophysiology in order to develop a useful experimental instrument for research, namely to evaluate new therapeutic approaches in AD. Ideally, the animal model used for this kind of study should be reliable, affordable and allow researchers to quantify the symptoms that are usually induced by AD. Existing animal models of $\mathrm{AD}$ are generally explored in mice dorsum $[5,16,18,19]$, abdomen and ears [20] and also in Wistar rats' dorsal skin [21]. This last animal model has been established through subcutaneous injection of capsaicin into newborn rat pups within $48 \mathrm{~h}$ of birth [21,22]. As a consequence, this $\mathrm{AD}$ model in rat authentically represents the chronically relapsing pruritic dermatitis, similar to human $\mathrm{AD}$, but it does not represent the characteristic cutaneous injuries of the disease.

In our protocol, an AD-like disease was induced in Wistar rats through repeated exposure to acetone of previously prepared dorsal skin. The obtained skin lesions were visually very similar to those observed in human $\mathrm{AD}$, showing various degrees of signs and symptoms such as deep excoriation and increased microcirculation in addition to those signs related to skin dryness such as scaly, rough, fissured and cracked surface. These were also biometrically quantified by elevated local blood flow, TWEL and lower hydration.

Skin dryness results from the reduction in the water-holding capacity of the stratum corneum (SC), which is also related to the cutaneous barrier function $[5,19,23,24]$. The cutaneous barrier impairment is normally revealed by a consistent increase in TEWL [19]. In the present study, acetone exposure of the rat's dorsum modified the epidermal barrier function, as demonstrated by the increase in TEWL and reduced the skin hydration (Fig. 2), resulting in dry skin. Previous studies have shown that acetone exposure on hairless mice removes SC lipid components, resulting in an acute barrier obliteration $[25,26]$ and TEWL increase, in addition to a SC hydration reduction in the first hour after exposure [5]. Thus, the acetone exposed area re-
A análise comportamental de coçar, mensurado pelo número de ações de coçar durante $30 \mathrm{~min}$, também aumentou significativamente após 3 dias de exposição à acetona, aumentando significativamente $(p=0,0090)$, quando comparado ao grupo controlo (Tabela 1 e Figura 3 ).

\section{Discussão}

Os mecanismos celulares e moleculares que causam a DA são ainda pouco entendidos, em parte devido às limitações das atuais metodologias de pesquisa in vitro e da escassez de modelos adequados.

O principal objetivo para este modelo animal é a replicação da mais relevante característica identificada na fisiopatologia da DA humana, a fim de desenvolver uma ferramenta experimental útil para a pesquisa na avaliação de novas abordagens terapêuticas na DA. Idealmente, o modelo animal utilizado para este tipo de estudo deve ser confiável, acessível e permitir quantificar os sintomas usualmente induzidos pela DA. Os modelos animais de DA existentes são geralmente explorados utilizando o dorso $[5,16,18,19]$, abdômen e orelhas [20] de camundongos, assim somo o dorso de ratos Wistar [21]. Este último modelo animal tem sido estabelecido através de injeção subcutânea de capsaicina em ratos recém-nascidos dentro de 48h após o nascimento [21,22]. Como resultado, este modelo de DA em ratos representa autenticamente a dermatite pruriginosa crônica recidivante, semelhante à DA humana, porém não representa as lesões cutâneas características da doença.

Em nosso protocolo, a DA foi induzida em ratos Wistar através da exposição repetida da pele dorsal previamente depilada à acetona. As lesões cutâneas obtidas foram visualmente muito semelhantes às observadas na DA humana, mostrando vários graus de sinais e sintomas, como escoriações profundas e aumento da microcirculação, além dos sinais relacionados com a secura da pele, como a presença da superfície escamosa, áspera, e fissurada. Tais sinais foram biometricamente caracterizados pelo elevado fluxo sanguíneo local, TEWL e menor hidratação.

A secura da pele resulta da diminuição da capacidade de retenção de água pelo stratum corneum (SC) e está relacionada com a função de barreira cutânea $[5,19,23,24]$. O comprometimento da barreira cutânea é normalmente demonstrado pelo aumento na TEWL [19]. No presente estudo, a exposição da pele dorsal dos ratos à acetona modificou a função de barreira da epiderme, como demonstrado pelo aumento da TEWL e redução da hidratação superficial (Figura 2), resultando em pele seca. Estudos anteriores têm demonstrado que a exposição da pele dorsal de camundongos hairless à acetona remove componentes lipídicos do SC, resultando no compro- 
produced the most prevalent condition manifested in $\mathrm{AD}$, that is, dry skin.

After acetone exposure a significant increase in the local capillary blood flow was also registered. Such an event is related to the barrier's integrity [27] and suggests a reaction to the acetone-induced skin dryness. Barrier dysfunction might amplify the response to acetoneinduced irritating stimuli and promote its inflammatory potential via a modulation of signal molecules [28]. A recent paper demonstrated that female volunteers with sensitive skin had capillary blood flow decreased after flaxseed oil supplementation, suggesting an improved epidermal function and a modulated inflammation dependent of signaling molecules [27].

The pruritus or itching accompanies several skin disorders, such as AD which promotes scratching and is responsible for additional related lesions [29]. One important finding in the present experiment is that repeated cutaneous exposure to acetone increased action of scratching in rats. The skin dryness might be a more important cause of scratching than the barrier impairment [19]. Thus, in this sense, the scratching behavior may be considered as an expression of the itch response and can be used as an indicator for the screening test of anti-pruritic drugs [19].

\section{Conclusion}

These results suggest the obvious usefulness of acetone to induce a human AD-like condition in Wistar rats. With this model, skin injuries are easy to evoke and promptly reproducible, animal stress is reduced and the cost is very acceptable. So, this model might be especially interesting for AD pathophysiology basic research to assess the efficacy of new therapeutic approaches in human $\mathrm{AD}$.

\section{Conflict of Interest}

The authors declare that there is no financial or personal relationship that can be understood as representing a potential conflict of interest.

\section{Acknowledgements}

Fapergs/PQ Gaúcho 2011; PROAP/PPG-Farmacologia PRPGP-UFSM. R.C.S.B. is grateful to CAPES (Proc. $\left.\mathrm{n}^{\circ} 12241 / 12-1\right)$ metimento agudo da barreira cutânea $[25,26]$ aumentando a TEWL, além de reduzira hidratação do SC na primeira hora após a exposição [5]. Nesse contexto, a área dorsal exposta à acetona (AA) reproduziu a condição mais prevalente manifestada na $\mathrm{DA}$, a pele seca. Após a exposição à acetona, foi também registrado um aumento significativo no fluxo sanguíneo capilar local. Tal evento está relacionado com a integridade da barreira cutânea [27] e sugere uma reação para a secura da pele induzida pela acetona. A disfunção da barreira cutânea pode amplificar a resposta a estímulos irritantes induzidos pela acetona e promover uma reação inflamatória através de uma modulação das moléculas sinalizadoras [28]. Um estudo recente demonstrou que mulheres voluntárias com pele sensível tiveram o fluxo sanguíneo capilar diminuído após a suplementação com óleo de linhaça, sugerindo uma melhoria na função epidérmica, além da modulação da inflamação dependente de moléculas sinalizadoras [27].

O prurido acompanha várias doenças de pele como a DA, promove a acção de coçar e é responsável por lesões adicionais relacionadas [29]. Um importante achado da presente experiência é que a exposição cutânea repetida à acetona aumentou a frequência do coçar nos ratos. O ressecamento da pele pode ser a principal causa para o coçar, mais que o comprometimento da barreira cutânea [19]. Neste sentido, o coçar pode ser considerado como uma expressão da resposta pruriginosa e pode ser usado como um indicador para a pesquisa de drogas antipruriginosas [19].

\section{Conclusão}

Estes resultados sugerem a utilidade da acetona para induzir uma condição dermatológica que mimetiza a DA humana em ratos Wistar. Com este modelo, as lesões de pele são facilmente induzíveis e prontamente reprodutíveis, e o estresse animal é reduzido, além do custo muito aceitável. Assim, este modelo pode ser especialmente interessante para a pesquisa básica da fisiopatologia da DA, bem como para a avaliação da eficácia de novas abordagens terapêuticas da DA humana.

\section{Conflito de interesses}

Os autores declaram que não há nenhuma relação financeira ou pessoal, que possa ser entendida como um potencial conflito de interesses.

\section{Agradecimentos}

A Fapergs/PQGaúcho 2011; PROAP/PPG-Farmacologia PRPGP-UFSM e CAPES (Proc. ${ }^{\circ}{ }^{\circ}$ 12241/12-1). 


\section{References / Referências}

[1] Matts PJ, Gray J, Rawlings AV. The 'dry skin cycle' - A new intervention model of dry skin and mechanisms for intervention. ICSS 2005;256:1-38

[2] Kitamura, K. Advances in dry skin care technology extend beyond the category of cosmetic products. IFSCC Magazine 2002;5:177-187.

[3] Norman RA. Xerosis and pruritus in the elderly: recognition and management. DermatolTher 2003;16:254-259

[4] Nojima H, Cartens MI, Cartens EC. C-fos expression in superficial dorsal horn of cervical spinal cord associated with spontaneous scratching in rats with dry skin. NeurosciLett 2003:347:62-64.

[5] Tominaga M, Ozawa S, Tengara S, Ogawa H, Takamori K. Intraepidermal nerve fibers increase in dry skin of acetone-treated mice. J DermatolSci 2007;48:103-111.

[7] DiNicola C, Kekevian A, Chang C. Integrative Medicine as Adjunct Therapy in the Treatmentof Atopic Dermatitis - the Role of Traditional ChineseMedicine. Dietary Supplements, and Other Modalities. Clinic Rev AllergImmunol 2013;44:242-253.

[8] Stensen L, Thomsen SF, Backer V. Change in prevalence ofatopic dermatitis between 1986 and 2001 among children. AllergyAsthma Proc 2008;29:392-396.

[10] Pfab F, Schalock PC, Napadow V, Athanasiadis GI,Ring J, Huss-Marp J. Complementary integrative medicine in atopic diseases - an overview. Focus on Alternative and ComplTher 2013;18(2):77-84.

[12] Leung TF, Wong KY, Wong CK, Fung KP, Lam CW, Fok TF, Leung PC, Hon KL. In vit$r o$ and clinical immunomodulatory effects of a novelPentaherbs concoction for atopic dermatitis. Br J Dermatol 2008;158:1216-1223.
[13] World Medical, Association. Declaration of Helsinki. 2008.

[14] EEC Directive (86/609/EEC)

[15] Portuguese laws D.R. no 31/92, D.R. 153 I-A $67 / 92$.

[16] Okawa T, Yamaguchi Y, Takada S, Sakai Y, Numata N, Nakamura F, Nagashima Y, Ikezawa Z, Aihara M. Oral administration of collagen tripeptide improves dryness and pruritus in the acetone-induced dry skin model. Journal of Dermatological Science 66 (2012) 136-143

[17] Akasaka Y, Yoshida T, Tsukahara M, Hatta A, Inoue H. Glycyrrhetinic acid prevents cutaneous scratching behavior in mice elicited by substance P or PAR-2 agonist. Eur J Pharmacol 2011;670:175-9.

[18] Kamo A, Tominaga M, Tengara S, Ogawa H, Takamori K. Inhibitory effects of UV-based therapy on dry skin-inducible nerve growth in acetone-treated mice. J DermatolSci 2011;62:91-97.

[19] Miyamoto T, Nojima H, Shinkado T, Nakahashi T, Kuraishi Y. Itch-associated response induced by experimental dry skin in mice. Jpn J Phamacol 2002;88:285-292.

[20] Ngatu NR, Okajima MK, Yokogawa M,Hirota R, Takaishi M, Eitoku M, Muzembo BA, Sabah AB, Saruta T, Miyamura M, Kaneko T,Sano S, Suganuma N. AntiAllergic Effects of Vernoniaamygdalina Leaf Extracts inHapten-Induced AtopicDermatitis-Like Disease in Mice. AllergolInt 2012;61:597-607.

[21] Back SK, Jeong KY, Li C, Lee J, Lee SB, Na SH. Chronically relapsing pruritic dermatitis in the rats treated as neonate with capsaicin; a potential rat model of human atopic dermatitis. J DermatolSci 2012;67:111-119.
[22] Kim YI, Na HS, Han JS, Hong SK. Critical role of the capsaicin-sensitive nervefibers in the development of the causalgic symptoms produced by transectingsome but not all of the nerves innervating the rat tail. J Neurosci 1995;15:4133-9.

[23] Chandar P, Nole G, Johnson AW. Understanding natural moisturizing mechanisms: Implications for moisturizer technology. $\mathrm{Cu}$ tis 2009;84(Suppl 1):2-15.

[24] Leveque JL, Grove G, de Rigal J, Corcuff P, Kligman AM, Saint Leger D. Biophysical characterization of dry facial skin. J Soc CosmetChem1987;82:171-177.

[25] Grubauer G, Feingold KR, Harris RM, Elias PM. Lipid content and lipid type as determinants of the epidermal permeability barrier. J Lipid Res 1989a;30:89-96.

[26] Grubauer G, Elias PM, Feingold KR. Transepidermal water loss: the signal for recovery of barrier structure and function. J Lipid Res 1989b;30:323-33.

[27] Neukam K, Spirt SD, Stahl W, Bejot M, Maurette JM, Tronnier H, Heinrich U. Supplementation of Flaxseed Oil Diminishes Skin Sensitivity and Improves Skin Barrier Function and Condition. Skin PharmacolPhysiol 2011;24:67-74.

[28] Fluhr JW, Feingold KR, Elias PM. Transepidermal water loss reflects permeability barrier status: validation in human and rodent in vivo and ex vivomodels. Exp Dermatol 2006;15:483-92.

[29] Wahlgren, C.F., 1999. Itch and atopic dermatitis: an overview. J. Dermatol. 26, 770-779. 